\title{
Tumor Necrosis Factor Receptor Superfamily Member 9
}

National Cancer Institute

\section{Source}

National Cancer Institute. Tumor Necrosis Factor Receptor Superfamily Member 9. NCI

Thesaurus. Code C105113.

Tumor necrosis factor receptor superfamily member 9 (255 aa, $28 \mathrm{kDa}$ ) is encoded by the human TNFRSF9 gene. This protein plays a role in receptor signal transduction in activated T-lymphocytes. 